\title{
Social Capital: Rethinking Change What A Theory of Social Capital Reveals About Democratic Stability
}

\begin{abstract}
Democracy is often perceived to be in a state of crisis, with theorists ready to measure the perceived decline in democratic health. In this paper I aim to understand the implicit assumptions about democracy within the theory of social capital formulated by Robert Putnam. Normative assumptions expressed by such a theory can say more about democracy than the findings they present based on specific collections of data. A conceptual analysis of social capital is done through a historical overview of the term, by locating it within the philosophical debate between individualism and communitarianism, and by presenting empirical and theoretical counterarguments to its claims. Political participation and civic engagement is shown to not simply be declining, but rather traditional metrics no longer capture the reality of how politics is performed. Equally, certain forms of social capital generating networks are questioned regarding their perceived positive impact on democracy, as understood within a sociological framework. Finally a look at the phenomenon of populism is considered. Populism is reconceptualised as not necessarily signifying the crisis of democracy as a whole, but as an opportunity to reflect on representative politics and the current political paradigm.
\end{abstract}

Tijs Adams ${ }^{1}$

1 Tijs Adams received his Bachelors degree in Arts and Culture from Maastricht university in 2017. He is Currently doing a Masters in Social and Cultural Anthropology at the Catholic University of Leuven, Belgium. 


\section{Introduction}

"Enlightenment is man's emergence from his self-imposed nonage. Nonage is the inability to use one's own understanding without another's guidance. This nonage is self-imposed if its cause lies not in lack of understanding but in indecision and lack of courage to use one's own mind without another's guidance. Dare to know! (Sapere aude.) "Have the courage to use your own understanding," is therefore the motto of the enlightenment." 2

\section{- Immanuel Kant, 1784}

In the western world, there are few who do not endorse democracy as the best viable form of governance. Nevertheless, many readily claim that in its current embodiment democracy is not functioning as it should. Scholars eagerly formulate theories about why this might be the case and provide vast amounts of evidence to defend their claims. It is precisely those theories, both on the theoretical and empirical level that I will examine in this chapter. Within any theory about why a democracy is failing there are implicit normative assumptions about what, conversely, a healthy should look like. This then brings up the question whether an ideal form of democracy ultimately exists. Does it necessarily include a representational system in which elected politicians voice the concerns of their constituents? Which values are more important for democratic citizens, liberty and/or equality, and what is the relationship between the individual and groups in a democratic nation? Yet before any proclamations about the future of democratic governance can be made, tentative though they may be, it is helpful to look back to when democracy made its reappearance into the Western political arena during the nineteenth century. It was also during this period from which the quote of Immanuel Kant comes, reflecting the intellectual spirit of the Enlightenment in which traditional societies slowly gave way to individual rights and increased pressures for legal recognition of all citizens. These changes set the scene for democratization processes throughout Europe and beyond.

In Democracy in America (2003) Alexis de Tocqueville recollected his travels to the, then still young, United States, where he believed the democratic project was implemented most successfully. Disillusioned by the terror of the French Revolution, Tocqueville saw in America a successful formula for keeping the potentially violent forces within democracy in check, and to this day his work remains strongly influential. Political scientists and sociologists alike often use it to justify claims on the state of contemporary democracy, though often they rely on specific interpretations of Tocqueville's work, as evidenced by people along the entire range of the political spectrum being able to use his arguments. Which interpretations of Tocqueville are used, and whether these

2 Retrieved on May 30 3017 from

<http://www.columbia.edu/acis/ets/CCREAD/etscc/kant.html> 
even remain relevant 150 years after they were written, is an equally relevant question when it comes to any analysis of democracy. One such theory that I will look at is that of social capital, with a particular focus on Robert Putnam's theory of social capital as presented in the book Bowling Alone (1995). Putnam analyses the state of social capital in America, which he claims to be in decline, warning that this threatens continued democratic stability. The main research question of this chapter follows from this, namely, what normative assumptions underlie the social capital theory of Robert Putnam, who claims to diagnose the health of democracy, and what, if anything, can such a theory tell us about democracy itself?

Putnam's work has inspired much debate, and in answering my question, I will look into those critics of his work, and also those who hold similar views. The first step in this conceptual analysis of social capital will include an investigation into what exactly Putnam asserts about social capital and how it relates to Democracy. Here a recollection of some of Tocqueville's main arguments will serve as a background for highlighting the history of the theory of social capital. From this I will look into the specific normative assumptions that I have identified as belonging to the philosophical debate between communitarians and individualists. Shlomo Avineri and Avner DeShalit (1992) present an overview of the debate between communitarian scholars such as Michael Sandel and Charles Taylor, and individualists such as John Rawls and Marilyn Friedman. These authors provide such an overview that shows the varying aims and methods incorporated in theories analysing the state of democracy. From this debate I will look into the empirical research on which Putnam relies to highlight the supposed decline in social capital. Stolle, Hooghe, and Micheletti (2005) question the changing nature of social capital, as they identify new ways in which it is manifested in political participation, and from this they conceive of new variables to both measure and understand the changing nature of social capital. From questioning how Social Capital is measured I analyse the theoretical arguments that relate it to democracy. Charles Tilly (2007), David Held (2006), and Bryan Turner (1993) all question Putnam's assumption that the trust emerging from social networks and norms of reciprocity, which social capital is said to entail, as they look into the relationship between trust and representative politics, and democratic governance in general. Finally I look at Simon Tormey (2015) who addresses the nature of representative politics and questions whether discontent with democracy is not simply directed at the current political paradigm. Paul Taggart (2004) and Margaret Canovan (1999) analyse the phenomenon of populism as it reflects much of the discontent of democracy that exists in the western world. They see populism as an opportunity to reflect on democratic values, and not solely as an antidemocratic movement. Social Capital theories have not been explicitly linked to populism, yet I believe that there is a strong correlation between those who see declining social capital as threat to democracy, and the concerns voiced by supposedly anti-democratic politicians and their supporters. By analysing the underlying normative assumptions of Putnam's theory on social capital and its relation to democracy, I ultimately aim to understand more about democracy itself. 


\section{Social Capital}

\subsection{The Origins of Social Capital}

"Is erosion of social capital an ineluctable consequence of modernity?" as Putnam asks at the end of Bowling Alone (1995, p. 367). Does the origin of the perceived decline in social capital lie in the Enlightenment, when traditional social ties were uprooted by progressive ideas such as democratic rule? The advent of modernity shaped our contemporary world, from the ways in which individuals conceive of themselves, to the organization of our political lives. Yet before such statements pertaining to the origins of declining social capital can be made, it is necessary to fully understand what a theory of social capital entails and, subsequently, how it relates to democracy. Though we now live in a globalized world marked by advanced telecommunications and information technologies that would hardly be recognizable to people of the nineteenth century, it is in that time period where an analysis of social capital begins. Though the term social capital had not been coined, Auguste Comte was formulating the new academic discipline of sociology, under which it is now studied.

The aim of this new science was to understand the natural, unchangeable laws that governed society, and ultimately eliminate the need for public debate, and ultimately dispersing with politics altogether (Malik, 2001, p. 92-93). Such a belief was made available through his positivist vision which saw science as containing "the key to social and moral problems", as it uncovered the "absolute truths of the laws of nature" (p. 93). This desire for certainty came after the French Revolution spiralled into terror, an event that also heavily influenced Tocqueville's work. In America, Tocqueville studied those social mores and political institutions which he believed to be important in the successful implementation of a democratic government. While the political institutions are a large factor in democracy's success, analysing them is beyond the scope of this chapter. Thus I limit my analysis to those nineteenth century American social norms as described by Tocqueville, who contends that before any institutional analysis "we must [...] start by studying the social condition" (2003, p. 43). What exactly those social conditions were, and how they relate to contemporary theories of social capital is what I will now examine.

The lasting influence of Tocqueville on theories of social capital is due to the importance of the voluntary associations he constantly saw Americans joining.

Americans of all ages, all stations in life, and all types of disposition are forever forming associations. There are not only commercial and industrial associations in which all take part, but others of a thousand different types - religious, moral, serious, futile, very general and very limited, immensely large and very minute .... Nothing in my view deserves more attention than the intellectual and moral associations in America.

(Tocqueville, 1835, as cited in Putnam, 2000, p. 48) 
Tocqueville assumed that "membership in associations [will] turn people into marginally better citizens by teaching them the routines of civilized conflict resolution as well as competent judgment about public affairs" (Putnam, 2002, p. 234). This was non-existent in traditional, aristocratic, and communityoriented society, which slowly gave way to a democratic, individualist society. The individualized democracy could take two forms according to Tocqueville; it could develop into a form of atomistic despotism, in which individuals are increasingly concerned with their own interests and have little concern for communal and public affairs, essentially leaving politics open for a small group of people to seize control. On the other hand, democracy could also become liberal, decentralized and participatory. Public-spirited mores and institutions of civil society would serve as a balance to the centrifugal force of democratic equality, which is what Tocqueville observed in America (p. 13). Putnam sees this importance of voluntary associationalism in terms of civic engagement, which, alongside political participation, he believes is a major contributing factor to the generation of social capital. Social capital, according to Putnam, is the "social networks and the norms of trust and reciprocity associated with them" (p. 5). Like both human and physical/financial capital, social capital is regarded as a measurable form of capital that can be beneficial to both the individual and the collective. Thus there is a strong similarity in how Tocqueville viewed associations in fostering mores that were conducive to a wellfunctioning democracy, and the norms or trust and reciprocity which Putnam identifies as resulting from social capital formed through civic engagement and political

participation.

As a concept, social capital has been coined numerous times during the twentieth century, before Putnam's conception, by scholars representing a diversity of disciplines. The first occurrence of the term was L. Judson Hanifan writing in 1916, who was convinced that the social, economic, and political problems of his community could be solved by strengthening the networks of solidarity amongst citizens. Social capital, Hanifan felt, would renew community involvement in order to sustain democracy and development, as it would promote the general improvement of the community's wellbeing. Six other instances of the term being invented took place during the twentieth century, by John Seely, Jane Jacobs, Glenn C. Loury, Pierre Bourdieu, Ekkehart Schlicht and James S. Coleman (Putnam, 2002, p. 5). I focus solely on Putnam's conception of social capital as he stresses that the characteristics of civil society, which are largely dependent on levels of social capital, "affect the health of our democracies, our communities, and ourselves" (p. 18). By focusing on the supposedly beneficial relationship between social capital and democratic governance, I thus aim to understand those normative assumptions regarding the form of a well-functioning, healthy democracy.

This is a highly relevant topic, as many believe democracy is currently not healthy, as evidenced by the success of populist politicians and antidemocratic sentiments that are apparent throughout society. Later in the chapter populism is discussed in more detail, but for now I use a wide understanding of populism as a reaction towards perceived individualism, internationalism, multiculturalism and the belief in progress (Canovan, 1999, p. 4). That such sentiments can hold root in society would be, according to Putnam, a result of the declining social capital that is taking place in most 
western, advanced liberal democracies, and not simply in the United States (Putnam, 2002, p. 409). For this reason I extend the conclusions from Bowling Alone, as the effects of social capital are not limited to a specific time or space, though measurements may only reflect its state in specific communities.

\subsection{Different Forms of Social Capital}

After having looked at the origins of social capital theories, I now turn to a more in-depth analysis of the specific contours, as it extends beyond simply the social connections within communities. Putnam presents evidence that eroding social capital has led to widespread discontent with liberal democracies' major institutions, including those of representative politics. The fundamental preconditions, both cultural and social, for effective democracy may have eroded as a result of the widespread process of civic disengagement. Putnam attempts to draw on empirical evidence to make these conclusions, but as he himself states, the "relevant characteristics of civil society - the contours of social capital - vary systematically over time and space" (2002, p. 6). Later I will look more in depth at how the indicators of social capital have been redefined to fit the changing conditions of contemporary society, but now I will look more at possible subdivisions within social capital, and how these relate to democracy. The associational landscape provides a highly uneven picture concerning both the social composition of the members and the coverage of substantive domains and issues. Their favourable impact on the quality of democratic governance must be limited by these biases and inequalities. To a large extent it is the interpretation of both the negative and positive aspects of social capital that determine whether the current models of measurement are seen as positive towards democratic governance.

This has led to debates between those who do not see measures of social capital as indicative of democratic stability, as well as scholars questioning exactly which forms produce positive externalities. Networks and norms might benefit those who belong - to the detriment of those who do not. Social capital might be the most prevalent among groups of people who are already advantaged, thereby widening political and economic inequalities between those groups and others who lack social capital. The basic question that must be asked is: Who benefits from social capital and who does not? Certain forms of social capital, according to Putnam, must therefore be good for social and democratic health, while others are, or threaten to be, destructive. Putnam offers four distinctions that exist in the debate on social capital.

The first distinction within social capital is that between formal and informal associations. Some associations, such as labour unions and parents' organizations are formally organized with extensive records of their operations and members (2002, p. 10). Historically such associations have been the focal point of research into social capital as they provide a stronger basis for empirical research. Informal associations range from gatherings at a café to playing a game of football. While Putnam recognizes that such forms "may be more instrumental than formal associations in achieving some valued purpose" ( $p$. $10)$, they remain methodologically inconvenient as they do not keep extensive records on participants nor operations. Thick social capital versus thin social 
capital constitutes the second division within Putnam's theory. Thick social capital is found in closely interwoven and multi stranded social networks, such as the family, or a group of workers whose relationship continues beyond working hours into such activities as going to the café together or attending the same religious centre (p. 10). Thick social capital is said to be more beneficial for social mobilization and social insurance. Thin social capital includes briefer, mostly invisible connections within a social network. Social networks are understood in a broad definition, as they include such interactions as smiling in a supermarket or chance encounters in an elevator. Such thin connections foster "broad norms of generalized reciprocity" and are "better for knitting a society together" (p.

Third, there exists inward-looking and outward-looking social capital. Inward looking social capital is created within groups commonly organized "along class, gender, or ethnic lines and exists to preserve or strengthen the bonds of birth and circumstance" (p. 11). Inward-looking networks promote the interests of their members along material, social, or political lines, and include such groups as labour unions. Outward-looking networks perform the opposite task, as these are concerned with public goods and exist in charity organizations structured around altruistic beliefs. An example would include an environmental movement, or membership in the International Red Cross. Putnam's fourth and final distinction within social capital exists between bridging and bonding social capital. Bridging social capital entails those networks that connect people of different ethnicity, age, social class, and gender together, while bonding social capital occurs within such groups constituted by members who are alike ( $p$. 11). Just as Putnam, I consider this an important distinction as "external effects of bridging networks are likely to be positive, while bonding networks [...] are at greater risk of producing negative externalities" (p. 11). Groups rely on support from their members, though it is important for a heterogeneous society to have bridging networks that cross-cut such apparent distinctions. Bonding and bridging may exist within one association or group, such as a church group where members of the same religion can represent different social classes or ethnicities. It is important to note here that most associations and social networks are hybrids of all four distinctions, making it difficult to quantify changes and whether a certain form of social capital produces positive effects. Putnam claims that on the aggregate social capital is declining, and as a result there are negative consequences for democratic health, or: "The presence of social capital helps to make democracy work" (p. 190).

\subsection{Trends in Social Capital}

From the onset it is important to note that social capital and well-functioning government institutions form a reciprocal relationship. The presence of high social capital fosters norms of trust and reciprocity which are reflected in the performance indicators of political institutions, whose presence in turn provides a fertile landscape for associations, which produce social capital, to flourish. Yet not all social capital contributes equally, as the fear that the new individualistic forms of civic engagement may be less productive to the pursuit of collective goals. Putnam believes the new forms are narrower, less bridging, and less focused on collective or public regarding purposes. They are, he concedes, more 
liberating, but less solidaristic, and represent a sort of privatization of social capital (Putnam, 2000, p. 45). Putnam thus prefers more formal, thick forms of social network over informal, thin ones as the latter are more individualistic, as opposed to the former which are more communal. This is reflected in his empirical research on declining social capital between 1973 and 1994 within the United States, as evidenced in Table 1.

\begin{tabular}{|l|c|}
\hline Activity & $\begin{array}{c}\text { Relative change 1973- } \\
74 \text { to } 1993-94\end{array}$ \\
\hline Served as an officer of some club or organization & $-42 \%$ \\
\hline Worked for a political party & $-42 \%$ \\
\hline Served on a committee for some local organization & $-39 \%$ \\
\hline Attended a public meeting on town or school affairs & $-35 \%$ \\
\hline Attended a political rally or speech & $-34 \%$ \\
\hline Participated in at least one of these twelve activities & $-25 \%$ \\
\hline Made a speech & $-24 \%$ \\
\hline Wrote congressman or senator & $-23 \%$ \\
\hline Signed a petition & $-22 \%$ \\
\hline Was a member of some "better government" group & $-19 \%$ \\
\hline Held or ran for political office & $-16 \%$ \\
\hline Wrote a letter to the paper & $-14 \%$ \\
\hline Wrote an article for a magazine or newspaper & $-10 \%$ \\
\hline
\end{tabular}

Table 1: Trends in political and community participation (Taken from Putnam, 2000, p.45)

Of the twelve activities falling under political participation, the majority occur within a strong communal context, such as working for a political party, a political club, or participating in a political rally. Figure 1 presents the same information regarding the waning participation in political rallies and political parties. 


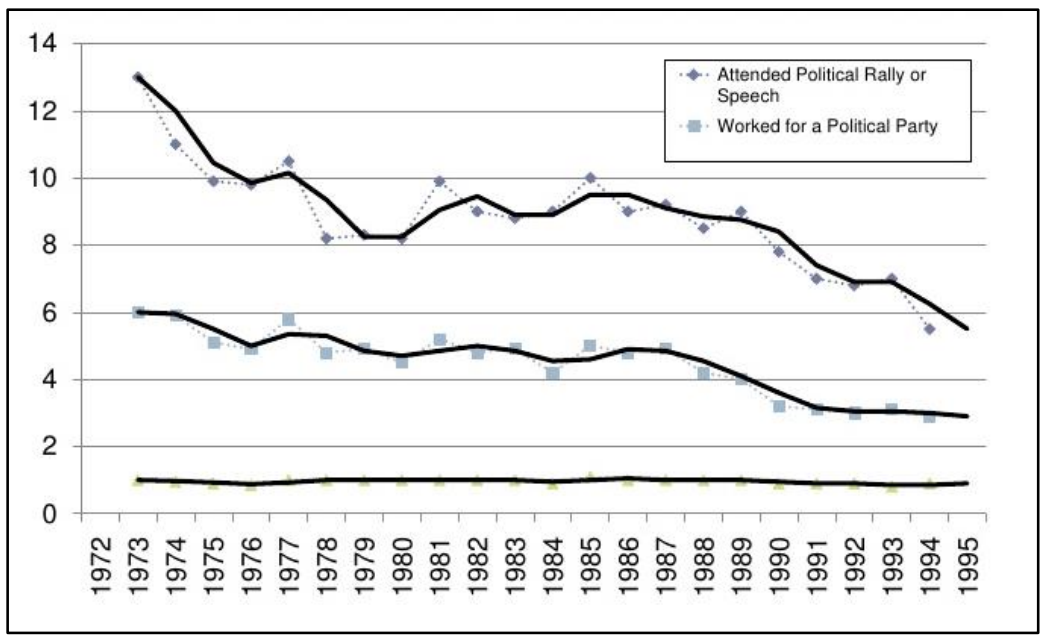

Figure 1: Trends in Civic Engagement: Partisan Activities (Taken from Putnam, 2000, p.61)

Again, using Putnam's distinctions between forms of social capital, attending rallies and belonging to a political party represent formal, thick types of social capital, and over the time period when the data were collected they showed the strongest decline, namely a $35 \%$ drop in public meetings, and a $40 \%$ drop in engagement in party politics (2000, p. 46). From this Putnam draws the tentative conclusion that perhaps "more Americans than ever before are "turned off" and "turned out" from politics" (p. 46). Besides political participation, civic engagement is equally a source of social capital that is conducive towards a society in which democracy can successfully operate. In figure 2 Putnam outlines the change in people who served as officer or on committee (or both) for local clubs or organizations measured between 1973 and 1994, showing roughly a 50\% drop in those people who participated in such activities. In figure 3 the mean number of club meetings of individuals between 1975 and 1999 equally shows a drop by more than 50\% (2000, p. 6061 ). Again these trends only seem to reflect those activities that produce more formal, thick forms of social capital, as they measure involvement in groups and activities that provide more data, which is also easier to analyse. There is, however, also statistical data on informal social activities as seen in figure 4, which represents such activities as eating dinner at a restaurant or attending a sporting event between 1975 and 1998. Within these activities there is generalized decline, though some, such as attending a sports game as a spectator, have shown steady increases from the 1960s up until the year 2000 (p. 114), from which Putnam draws the conclusion that "we spend more time watching and less time doing", both in civic activities and political participation (p. 115). 


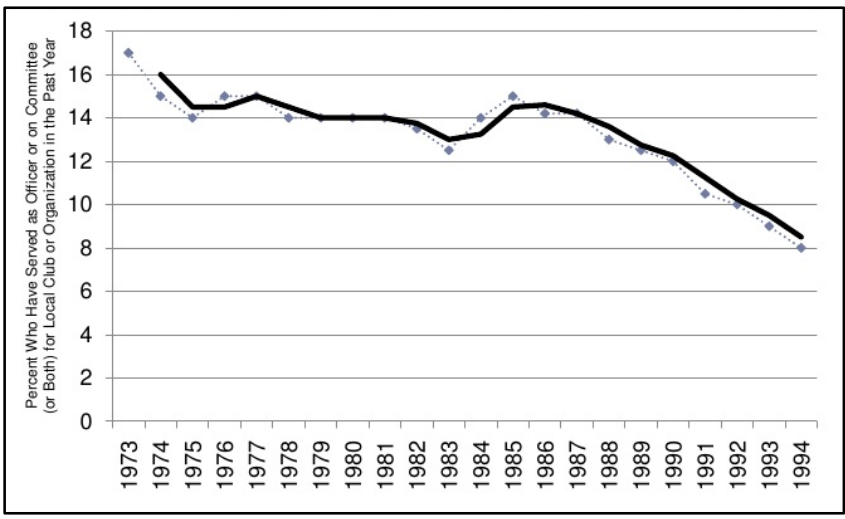

Figure 2: Active Organizational Involvement, 1973-1994 (Taken from Putnam, 2000, p.60)

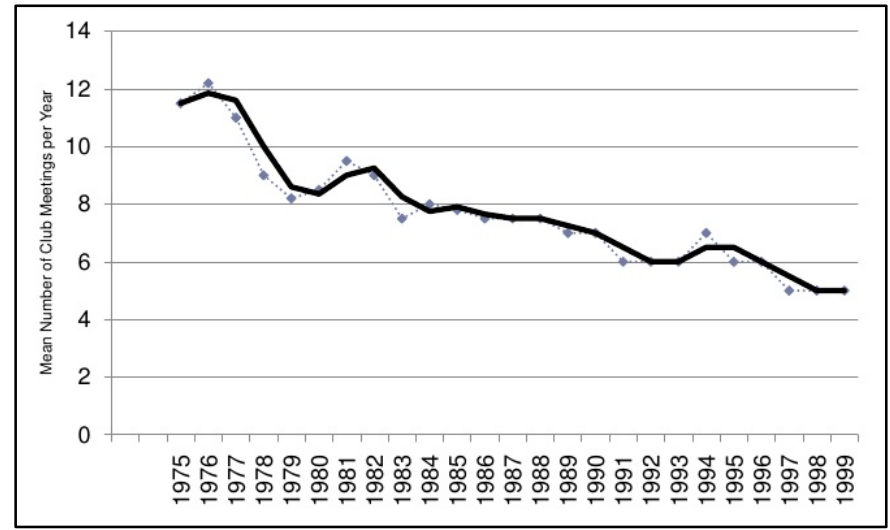

Figure 3: Club Meeting Attendance Dwindles, 1975-1999 (Taken from Putnam, 2000, p.41) 


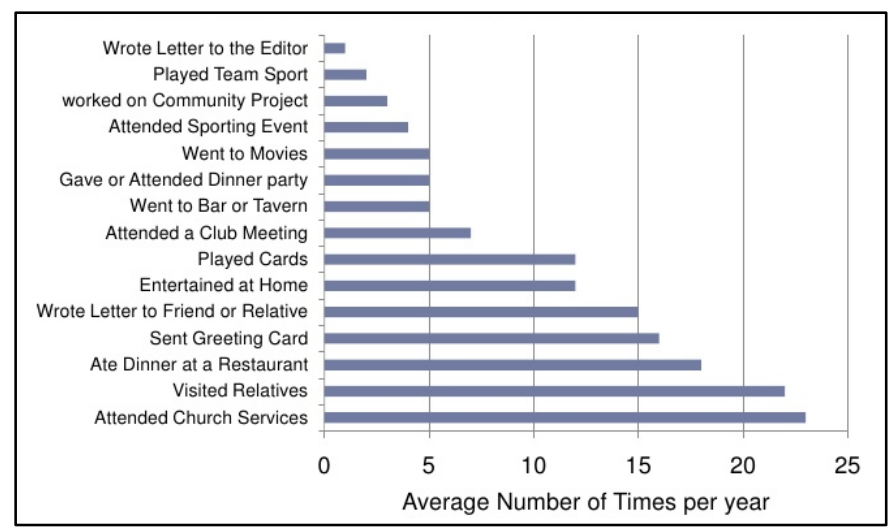

Figure 4: Frequency of Selected Formal and Informal Social Activities, 19751998 (Taken from Putnam, 2000, p.98)

In this part I have looked at the history of social capital theory, from the first theories of Tocqueville about the importance of associational life in the early American democracy, to its contemporary conceptualization by Putnam. Within that specific theory of social capital there exist further distinctions that arise out of the difficulty of classifying all forms of social networks as either positive and negative, or declining and increasing. Forms of political participation and civic engagement are complex and difficult to quantify, which is perhaps why Putnam's data reflect formal and thick variants of social networks, or those that predominantly keep records on participation and membership. Bridging and bonding social capital, and inward-looking as opposed to outward-looking forms of social capital, remain unexplored in respect to their positive and negative externalities and subsequent relationship towards democratic performance. The question "is social capital at war with liberty and tolerance" (2000, p. 351) is related to those exact dichotomies, as certain networks exert coercive pressure upon its members and foster intolerance towards those outside the community. I will now look at this question within the framework of the philosophical debate between communitarianism and individualism to understand the values attributed to communities in relation to their individual constituents within Putnam's theory of social capital with the aim of understanding how this frames his conception of a democratic society.

\section{Communitarianism and Individualism}

Tocqueville emphasized the importance of voluntary associational life in the United States as it reinforced communal oriented mores that stave off the everpresent danger of the tyranny of the majority. The preservation of individual liberty against this tyranny becomes an essential element of democracy (Tocqueville, 2003, p. 287-305). Tocqueville equally stresses the importance of 
equality within the United States, and within his book there is an inherent tension between liberty and equality, which has been a central tenet of western political debates (Putnam, 2000, p. 351). Yet Liberté and egalité are only two of the three ideals on the banner of the French Revolution, with the third one being Fraternité. Putnam identifies the ideal of Fraternité as social capital. The looming danger of the tyranny of the majority can be understood in this light, as "social capital might unacceptably infringe on freedom and justice" (p. 351). Can certain norms within those networks formed by associational life produce intolerance and coercion? In a chapter entitled 'the three races in the United States' Tocqueville expressed doubt whether "the white and black races will ever be brought anywhere to live of a footing of equality" (Tocqueville, 2003, p. 375), and while it is necessary to view such proclamations within their historical context, race, class, gender, and other minority groups remain divisive issues in contemporary societies. I look at the debate between individualism and communitarianism in the following part to understand how social capital, understood as a communal and individual good, stands in relation to freedom and tolerance.

\subsection{Individualism}

For this debate Avineri and de-Shalit (1992) present arguments pertaining to the main proponents of communitarian values, and those of individual values. The basic tenet of liberal thought is that the right has priority over the good. John Rawls (1971) reignited liberal thought as he extended the primacy of rights as a universal ideal applicable to all of humanity. His theory of justice is an attempt to base the ethical justification of the state on a thought experiment. The thought experiment rests on the belief that every individual has the ability to participate, regardless of his or her social condition. Rawls asks participants to enter what he calls the veil of ignorance beyond which individuals are in an original position, in which they are ignorant of any information about their beliefs, norms, class, status, gender, and so on (Avineri \& de-Shalit, 1992, p. 3 ). The intuitive idea is that there exists a link between ignorance and fairness. Such an unencumbered self, as the communitarian critic Sandel calls it, can serve as "a theoretical device to construct a theory likely to gain consensus in a society whose members are deeply divided on conceptions of the good" ( $p$. 3 ). This is an argument against moral relativism, and such relativism is no longer justifiable in a world where global awareness is made possible due to the large amounts of available information (p. 4). The aim of neutrality and objectivity can be achieved through universal generalizations about what moral principles are capable of being discovered. Parties entering the veil of ignorance are unaware of two things; firstly, they are unaware of their natural endowments (talents) and social position, and second, they do not know their conception of the good, though they do maintain "the capacity to frame, revise, and pursue a conception of the good" (Swift, 2006, p. 22). Rawls identifies two principles that would be attained beyond the veil of ignorance. First, each individual would have the equal right to the "most extensive total system of basic liberties compatible with a similar system of liberty for all" (p. 22). Second, social and economic relations would be rearranged to benefit the least advantaged and would be attached to "offices 
and positions open to all under conditions of fair opportunity" (p. 22), or the principle of equality of opportunity. In terms of social capital, it would seem that a society consisting of bridging social capital would be more conducive to a conception of the right as taking priority over the good. If different networks are connected through such processes as intercultural dialogue and recognition of individual rights, it is easier to establish a universal theory of justice such as Rawls'. If bonding social capital serves to "reinforce exclusive identities and homogenous groups" (Putnam, 2000, p. 22), and promotes the socio-economic status of its members, it becomes more difficult to rearrange the economic system to benefit the least advantaged. Even more than human and physical capital, social capital is "accumulated most among those who need it least" (Putnam, 2002, p. 415), evidencing how in reality social capital becomes increasingly accumulated within those already benefitting from it. One other important voice in the debate comes from Marilyn Friedman who represents the specific feminist criticism of communitarian arguments. Friedman's standpoint is that "communitarian theory, in the form in which it condones or tolerates traditional communal norms of gender subordination, is unacceptable" (as cited in Avinerdi \& de-Shalit, 1992, p. 103). As such she believes that many communitarian theorists make moral claims that do not properly recognize the "hierarchies of domination and subordination" (p. 104) on its members, and those specific communities that are often invoked, such as the family, neighbourhood, or nation represent a troubling paradigm in relation to gender relations. Such communities have historically been oppressive towards minorities and those with differing opinions, typically women, and it is a trend that continues today. There is little room for the individual to shape and contribute to the desired shape of the community, and Friedman concludes by saying that "the communities and loyalties of our found communities, our communities of origin, may harbour ambiguities, ambivalences, contradictions, and oppressions which complicate as well as constitute identity and which have to be sorted out, and critically scrutinized" (p. 112). Alongside ethnic issues, Tocqueville also discussed the relationship between men and women in American society. Of this relationship he said, "Americans [...] who have allowed the social inferiority of women to remain, have done their utmost to raise her intellectually and morally to man's level" (2003, p. 700). Whether keeping women within the domestic sphere can truly be considered as "understanding the true concept of democratic progress" ( $p$. 700 ) is questionable, though Tocqueville did express progressive views on gender equality for his time. Yet attributing equal worth in theory is far removed from actual equality in opportunity and the ability to self-identify. Looking back at the quote in the beginning of the text by Kant, it would seem that the onus falls on the individuals to liberate themselves from such oppressive structures, yet in many cases the power relations within social networks remain hidden and difficult to subvert. Kant's notion of using one's own understanding does apply to Rawls' thought experiment, as it assumes there exist basic principles which all participants can uncover, and thus conceive of a theory of justice beyond a socio-cultural context, or framed within a given political community. It follows that any state that inhibits their ability to recognize universal human capacities 
and worth is thus unjust; such a state presupposes a conception of the good life before acknowledging a conception of the right.

\subsection{Communitarianism}

It is precisely the Kantian underpinnings of Rawls' argument that communitarian theorists such as Michael Sandel criticize. Most contemporary communitarian criticism towards liberalism and individualism is based on two objections. The first is methodological, as they argue that the idea of the rational individual, who is able to choose freely outside a given community, is wrong. The only way to understand human behaviour as observed in an individual is by referring to them within their given social, cultural, and historical context. The second argument is normative, as communitarians view the idea of individualism giving rise to generalized morality as wrong. Certain conceptions of the good life should be sustained by the state, such as the distribution of goods, which does not require a preference for the right. An individual conception of morality would similarly not allow for a genuine community which can effectively tackle such issues as distribution of goods (Avineri \& de-Shalit, 1992, p. 3). As such most of the communitarian criticisms can be seen as a reaction against the individualist claim that individuals can be conceived of as autonomous agents outside the setting of a culture or society. Such an unencumbered 'self' is according to them an ontological impossibility.

Sandel's criticisms are based around the two general objections mentioned above. The basic questions which he aims to answer within his essay are "what is the political philosophy implicit in our practices and institutions" and "how do tensions in the philosophy find expression in the current political condition" (p. 15). He identifies the current liberal mind-set as pertaining to the vision of justice, fairness, and individual rights. The core thesis of this philosophy is that a just society does not seek to promote any particular ends, but enables its citizens to pursue their own ends, consistent with similar liberty for all. The governing body must not impose or promote any particular vision of the good, but must rather govern by adhering to the right, which is a moral category that takes precedence over the good. A just society does not presuppose a telos, or purpose, to which it aims, but rather it refuses to choose in advance between competing purposes and ends. Rights take priority over the good in two senses. The first is that the priority of right means that individuals cannot be sacrificed for the sake of the general good, which is in direct opposition to utilitarian thought. The second is that the principles of justice specifying such rights cannot be premised on any particular vision of the good life ( $p$. 17).

The vision of the unencumbered self rests on specific Kantian foundations; Kant defended the supremacy of moral law, and he framed moral law in relation to a categorical foundation, and not on contingent ones that are specific to each society. The basis then of this moral law is not empirical, but the subject capable of autonomous will must be made the grounds for all maxims of action. Only such a transcendental subject could "elevate man above himself [...] and enable him to participate in an ideal, unconditioned reality wholly independent of our social and psychological inclinations" (p. 18). Every human is capable of understanding this unconditional subject through our 
common and universal ability to reason, and only through the correct application of our reason can we participate in locating this transcendental subject. Sandel views Kant's inability to locate the universal ability of reason in a non-transcendental way as theoretical problem in regards to its implementation and validity.

As such this presents a methodological difficulty for liberal theorists, as they rely on vague transcendental notions to define those capabilities allowing them to universally reason which all humans possess a priori to, and independent from, their social, cultural, and historical context. The unencumbered self is thus denied the possibility of membership in any community that is bound by moral ties antecedent to choice, as these would impede the specific autonomous capabilities of the individual. According to Sandel, however, we can never view ourselves as independent with an identity never tied to our aims and attachments, as we are communal beings. A person would be without character if they did live independent from any such community. And to have character is to know that one moves within a history they neither summon nor command, which carries consequences nonetheless for their choices and conduct. The unencumbered selves aim to "reflect on their history and in this sense to distance themselves from it, but the distance is always precarious and provisional, with the point of reflecting never being finally secured outside the history itself" (p. 24). To further understand the importance of the social and cultural setting as conducive to the 'self', I look at the history of communitarianism, which starts with the Scottish founder of modern conservatism, Edmund Burke, who saw community as a partnership "not only between the living, but between those who are living, those who are dead, and those who are yet to be born" (Avineri \& de-Shalit, 1992, p. 2). The French Enlightenment thinker Rousseau conceived of a Social Contract that if agreed upon by all citizens would offer the opportunity for them to pursue ultimate freedom, which could only occur in such a communal setting. The German Philosopher Hegel saw the communities as providing Moralitat, or the abstracts or universal rules of morality and Sittlichkeit, or the ethical principles that underpin specific historically located communities (p. 3). Where liberals value the universal moralitat higher as it allows for a conception of the individual who stands as an entity unto himself, communitarians generally argue for sittlichkeit, as they believe this is the only guarantee of achieving genuine moral autonomy and freedom. Putnam can be identified with the communitarian mode of thought, for throughout his work communities are presented as the most immediate beneficiaries of social capital, which as a result producing negative consequences for the individual members. "Social capital greases the wheels that allow communities to advance smoothly" (Putnam, 2000, p. 288), and it is those communities' civic engagement and political participation, which in turn generate social capital. Again it is necessary to consider the parameters of a given community, and analyse how it is defined to uncover "who is inside and thus benefits from social capital and who is outside and does not" (p. 358). If a community is understood in a broad sense as a nation, does waning political participation indicate a necessarily negative development for the health of democracy? What if the organizational and institutional makeup of such a political community contains tensions and confining structures in which 
individuals can no longer identify themselves? Broadly speaking the criticisms against communitarian thought is pointed at the presupposed conception of the good imposed on a society and, as Friedman points out, this can lead to hierarchies of subordination and domination. In the following part I again look at social capital's perceived relation towards democratic health. If the existing form of democracy is used as the standard for empirical research on the perceived indicators of democratic performance, such as social capital, then those forms of political participation and civic engagement that fall outside the scope of conventional categories are ignored, marginalized, or viewed as necessarily anti-democratic. Tormey, however, believes that "those questioning the normative side of democracy are on the right track" (2015, p.4), meaning that what is not measured, and what is deemed insignificant can tell us about the implicit norms within a theory more than what is measured and is held as significant. The contemporary emergence of populist politics is viewed by many as such a threat to democracy. I will look at both empirical evidence and theoretical counterarguments opposed to the thesis that social capital is in decline resulting in a democratic crisis, in order to better understand phenomena perceived to be anti-democratic, such as populism.

\section{Criticisms of Social Capital as a Determinant of Democratic Health}

\subsection{Empirical Counterargument}

Earlier it was seen how forms of social capital, such thin or informal connections, pose a methodological difficulty. Formal networks of political participation and civic engagement contain more extensive data on membership, for example the attendance at political rallies or the amount of people who join political parties. As Tormey (2015) points out, "a lot of what we should call politics is labelled activism, protest, or mobilization. Real politics is of politicians, elections, political parties" (p. 6). Such operations falling outside the scope of mainstream politics, both by politicians and civilians, fall within the category of actions that are difficult to quantify. Yet despite them occurring at the fringes of society they are able to exert effective pressure on mainstream politics, and equally provide the basis for reflection on traditional forms of political participation. By addressing such issues as climate change, challenging the corruption of the elite, and turning back consumerism, these new forms of politics represent emerging reactions towards globalization and emerging technologies that are changing the nature and scope of politics. Eventually fringe issues become known to a wider public and become focal points of mainstream politics themselves. Yet the question arises whether these new forms can be perceived as political, and to what extent they actually exert any form of pressure.

Stolle, Hooghe, and Micheletti (2005) specifically look at these new forms of perceived political participation and question if an empirical study is in 
fact possible, as they lay out the difficulties found in conducting research and quantifying such fluid forms of action. They present four major difficulties in measuring such sporadic and individual forms (p. 250). The first is that they do not know how many people engage in the emerging acts. This is due to the basic fact that they represent informal modes of social capital, as Putnam would put it, and thus there are no official registries or organizations that keep extensive data. The act of conscious or political consumerism, where people pay attention to the brands they buy, and boycott or promote certain products based on such perceived political factors, is to a large extent a private act. An example of political consumerism would include the preference towards fair trade goods, or abstention from others based on ethical concerns related to their production. Numbers exist regarding the sales of certain goods, such as fair trade coffee beans, in comparison to alternative yet similar goods, but this leads to the second problem to the empirical study, namely that it is hard to know the political character of these forms of participation. Does buying one good over another truly represent a political act? There could be other determinants such as personal preference based on non-political factors, yet it is hard to distinguish the motivational character of independent, informal acts of perceived political participation. Figure 5 (see appendix $B$ ) is taken from Putnam (2000, p. 97) and it reflects what he categorizes as social and leisure activities. These activities in themselves can be political, as the decision to dine at a certain restaurant or attend a country club can be influenced by political factors. Herein lies the difficulty in allocating the motivation behind such choices.

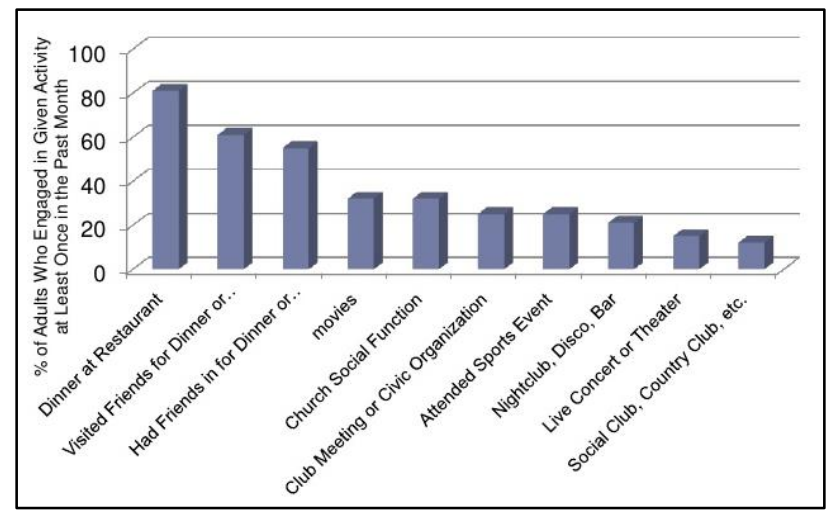

Figure 5: Social and Leisure Activities of American Adults (1986-1990) (Taken from Putnam, 2000, p.97)

The third difficulty is tied to this, as the study forces researchers to reconsider where to locate political participation. Does it occur on the local, regional, national, or global level? It is sometimes difficult to see the intended outcomes of such a diffuse range of acts. Here again the debate between individualism and communitarianism is relevant, as a communitarian conception of individuals states that they are constituted by the community to which they belong. The scope of such a community can change, which has 
implications on the duties people have towards each other. A global conception of a community is more conducive to liberal theories that claim universal rights for everyone, and so move beyond the traditional scope of political communities. Fourth, there is the question whether citizens who use these forms of participation turn away from national politics and national political institutions (p. 251). Does one form of participation cancel out the possibility of performing others? Can waning numbers in traditional metrics used to measure political participation, such as the ones employed by Putnam, be replaced by other forms that are equally valid? Stolle, Hooghe, and Micheletti do indeed conduct a series of surveys, as seen in table 2, which show that there are increasing trends in such informal modes of political participation. Their study focuses on political consumerism in Belgium, Canada, and Sweden, and measures the extent to which people participate in the boycotting of certain goods. $65 \%$ of respondents believe that boycotting is an effective method to exert pressure, and $69 \%$ view the individual as responsible for choosing the 'right' brands when shopping. Their survey concludes that political consumers are not "as disconnected from political processes as they expected" (p. 263).

\begin{tabular}{|c|c|c|c|c|c|c|}
\hline & $\begin{array}{c}\text { Canada } \\
(\%)\end{array}$ & $\begin{array}{l}\text { Belgium } \\
(\%)\end{array}$ & $\begin{array}{l}\text { Sweden } \\
(\%)\end{array}$ & $\begin{array}{l}\text { All } \\
(\%)\end{array}$ & $\begin{array}{l}\text { Factor } \\
\text { load }\end{array}$ & $\begin{array}{l}\text { Cronbach's } \alpha \\
\text { without item }\end{array}$ \\
\hline \multicolumn{7}{|c|}{ Percentage of respondents who believe in: } \\
\hline Effectiveness of boycotts & 66 & 51 & 69 & 65 & .46 & .87 \\
\hline $\begin{array}{l}\text { Personal responsibility to choose } \\
\text { the "right" company }\end{array}$ & 70 & 53 & 73 & 69 & .50 & .86 \\
\hline \multicolumn{7}{|c|}{ Percentage of respondents who use ethical considerations when buying*: } \\
\hline Groceries & 57 & 62 & 71 & 63 & .75 & .85 \\
\hline Soaps and detergents & 43 & 45 & 68 & 53 & .70 & .85 \\
\hline Restaurants & 50 & 51 & 39 & 45 & .58 & .86 \\
\hline Paper for school & 34 & 49 & 52 & 44 & 62 & .85 \\
\hline Clothes & 50 & 37 & 34 & 41 & .73 & .85 \\
\hline Shoes & 41 & 30 & 29 & 34 & .71 & .85 \\
\hline Banks & 33 & 46 & 29 & 34 & .49 & .86 \\
\hline \multicolumn{7}{|c|}{$\begin{array}{l}\text { Percentage of respondents who made purchases based on ethical or political } \\
\text { considerations in the preceding } 12 \text { months: }\end{array}$} \\
\hline $\begin{array}{l}\text { Buying some products over } \\
\text { others }\end{array}$ & 72 & 52 & 82 & 72 & 63 & .85 \\
\hline Boycotting products & 65 & 42 & 70 & 63 & .65 & .85 \\
\hline $\begin{array}{l}\text { Frequency of buying products for } \\
\text { political/ethical reasons } \\
\text { (buying nearly every time they } \\
\text { go shopping) }\end{array}$ & 13 & 8 & 27 & 17 & .80 & .85 \\
\hline $\begin{array}{l}\text { Frequency of boycotting } \\
\text { (boycotting nearly every time } \\
\text { they go shopping) }\end{array}$ & 13 & 7 & 21 & 15 & .76 & .85 \\
\hline
\end{tabular}

Table 2: Measures of political consumerism index (Taken from Stolle, Hooghe \& Micheletti, 2005, p.256) 
On the contrary, those who are aware of such things as political consumerism and the more informal ways of exerting political pressure are more likely to be engaged in other forms of political participation and group involvement. They also note that such acts of political consumerism are, in fact, highly individualized. This, far from being a solely negative aspect, is balanced by the fact that political consumerism is embedded in collective societal and political values (p. 263). They add, "political consumerism focuses less directly on influencing the governments of democracy and more on changing corporations, international organizations, and general labour and production practices"

(p.

263).

Jason Kaufman (2003, as cited in Tilly, 2007) similarly offers criticism of Putnam's empirical research, claiming he did not ignore important domains of political participation and civic engagement, but rather that he misinterpreted the available data. Kaufman analysed associational life in America during the nineteenth century, and carried over his research into the twentieth. From this he drew five conclusions, the first being that associational life in America already started declining after the First World War (2007, p. 90). In this he differs from Putnam, who sees historical ebbs and flows in the patterns of associational life, and locates the origins of the current state of decline in the period after the 1950s. The second point is that those associations, which saw membership decline, served parochial interests, rather than the general good. In Putnam's terms this would imply a decline in bonding social capital, which is rather exclusionary and can serve to reinforce homogeneity and similar viewpoints at the expense of minority views and different opinions. Third, those associations that declined thrived on combinations of exclusion, sociability and security. They did this by providing mutual aid for immigrants from a similar region, and thus neglecting those outside their conceived communities. This is related to the second point, which shows that very little, if any, bridging between communities took place. The fourth point Kaufman argues is that these associations whose origins lie in the nineteenth century contributed to the segmentation of American political and social life (p. 90). The fifth point is that overall the decline in associations was on balance a good thing. This counters such calls for new volunteerism in the old associations as "it implies that a new proliferation of voluntary association could easily advance parochial interests, instead of serving democracy" (p. 91). In terms of the liberal theorists discussed above, such associations apply a preexistent conception of the good onto its members, by which their actions are judged, thus viewing dissenting opinions as destructive and counterproductive.

\subsection{Theoretical Counterargument}

In this part I look at specific criticisms of the normative assumptions within Putnam's theory of social capital in relation to democracy. Firstly it seems that the conclusions he draws are based in a specific paradigm of democracy, namely representative politics. Representation is almost seen as an integral aspect of democracy that stands outside of any criticism. Yet already during the eighteenth century Rousseau was critical of the idea that representatives would voice the concerns of the entire populace. In his social contract theory he believed that "sovereignty originates in the people, and it ought to stay there" 
(Held, 2006, p. 46). Rousseau, and other nineteenth century critics such as Karl Marx, saw representation as serving the interests of the elite, who falsely claimed that they were caring for the needs of the many, but were rather serving their own interests. This was profoundly undemocratic for them, and their ideas echo in such contemporary theories as the one presented by Kaufman, who sees certain associations and forms of political participation as serving parochial interests. Tilly addresses Putnam's theory directly, as he sees the perceived trust originating from social capital, along with the networks producing it, as not a necessarily democratic idea. He claims that "On the side of government institutions, Putnam drifts into interpreting more effective institutions as more democratic" (2007, p. 91), for trust lubricates institutional effectiveness. Equally, Tilly argues that "on the side of civic engagement, Putnam begins to treat organizational networks, social capital, norms of reciprocity, and fabrics of trust as closely connected or even equivalent elements"

91).

The conclusions basing trust as a necessary precondition for certain political and social functions might be true under certain circumstances. One such important set of circumstances is identified by Tormey, who claims that "within already relatively democratic regimes, people who engage in civic organizations are more likely to meet their collective obligations, to press for better government performance, and to trust their fellow citizens" (p. 92). Thus there is a mistake in assuming the causal relationship between trust and democracy. And equally, a measure of distrust can be seen as conducive to successful democracy. Scholars such as Mark Warren (1999 as cited in Tilly, 2007) believe that there is a contradiction between public politics and trust. Warren see politics as a combination of conflicts over goods, pressures to associate for collective action, and attempts to produce collectively binging decisions. All occur more in democracies, but precisely those processes threaten naturally accumulated trust, as people in democracies find themselves becoming more equal and so competing on equal grounds for those same goals. This in turn can lead to growing resentment, as the scarcity of goods can generate dissension, collective action brings us-them boundaries into play, and collectively binding decisions mean unequal realization of individual and group interests (p. 93). Not only does democracy diminish naturally occurring trust relations, but distrust is itself a necessary element in the checks and balances of democratic governance, "as it keeps pressure on the existing government" (p. 94), and so becomes a necessary condition for democracy. Rather than blindly placing faith in the representative leaders, citizens must actively question and be critical of those that claim to be representing their desires. Equally, if political consumerism as outlined above is considered as a form of political participation, a degree of distrust is necessary when it comes to the consumption of certain goods, as scepticism towards the motivation behind corporations and producers of goods is often beneficial.

Even if trust were a necessary good for democracy, it is not necessarily in decline, for social capital producing networks are forever changing, and so the conception of trust itself must be fluid. Informal, thin networks consisting of loose connections between individuals and communities, occur over long distances and are sporadic. However, they generate new forms of trust, and "link people together in communities of interest" (Wuthnow, 2002, p. 179) who 
would otherwise not be in contact and so unaware of each others existence. With the nature of politics changing, so too is the importance and conceptualization of trust. However, Putnam's theory is not only criticized for its assumption that trust is a necessary good for democracy. Tormey questions the negative aspects allocated to individualism within the social capital theory, specifically Putnam's belief that individualism is necessarily bad for the individual, as well as being a disaster for politics and concerns of the common good and collective life (2015, p. 75). Tormey views the distinctly modern phenomenon of individualization differently. Rather than seeing a heterogeneous mass of atomized individuals ultimately serving the needs of the elite, "other readings of modernity emphasize the centrality of what is sometimes referred to as 'reflexivity' to understanding the nature of contemporary subjectivity" ( $p$. 76). This reflexivity is seen by Tormey as the ability to question tradition, authority and identities that are given by passed down social relationships. As evidenced earlier in the debate between individualism and communitarianism, any preconceived notion of the good life is an infringement on the rights and ability to self-determination that liberal theories claim. I refer again to the quote at the beginning offered by Kant, as it emphasizes how casting off those traditional and authoritative customs and beliefs may be painful at first, yet ultimately they are necessary for individual and societal

growth.

The same holds for democracy, for when "modernity unsettles congealed practices and traditions and the position of those who guard them", Tormey believes this should be "celebrated, not lamented" (p. 77). He contends that we, as citizens, are increasingly discontented with representative politics, yet contemporary political scientists are quick to measure a 'crisis' of democracy, as they view our "willingness to trust and respect our representatives to govern on our behalf" as quintessentially democratic (p. 1315 ). In the next part I will look at the recent phenomenon of populism, as it has become a widely used term to classify politicians and policies that are perceived as anti-democratic. The fear of such populist politicians, such as Marine Le Pen in France, and Donald Trump in the United States, is that they might "pursue an agenda that might worsen democratic engagement and public discourse rather than address it in a positive and constructive way" (p. 62).

\subsection{Case of Populism}

While the term populism is widely applied in political commentary, it remains a contested concept, and differences between the policies of various parties presents difficulties when trying to group them together for analysis. There exists both right wing and left wing populism, and populism directed at distinct issues, such as the European Union. Taggart (2004) approaches populism as an ideal type, looking at the similarities between the various parties and politicians, and he comes up with identifiable five features they share. First is the hostility towards representative politics, while simultaneously relying on representative forms of government to come into being. The complexities of representative politics prove frustrating, and often coupled with the discontent is the call for more direct democracy and participation by the citizens (p. 273). Second, populists claim to represent an idealized conception of community, or 
the "heartland" (p. 274), which they base on a specific interpretation of that community's history. Thirdly, populism lacks any core values, which is echoed in the difficulty of defining the concept, and therefore it is "substantially contextually contingent" (p. 275). The fourth shared feature of populist movements is their reactionary character, which is most apparent during perceived moments of crisis, often accompanying change, and not necessarily actual moments of crisis. Fifth is the self-limiting quality of populism. Due to its reactionary character and anti-establishment rhetoric, populism is not sustainable in the long term, for political parties soon find themselves institutionalizing to functioning within the political system (p. 276).

Do all these shared characteristics mean that populism is necessarily opposed to democracy, or that it is a symptom of an unhealthy democracy? Viewed in terms of social capital theories it would seem that a decline in social capital would correspond to such forms of politics. Declining social capital, according to Putnam, means both a declining trust in politicians and in the other members of society. Such conditions correspond to the necessary preconditions for populist politics as defined by Taggart. Malik contends that the recent success of populist politicians "reveals a problem with politics, not democracy" (2017).

Canovan (1999) believes there is an inherent contradiction within democracy that could explain the recent rise in populist parties. If populist parties claim to represent the popular will of the people, however elusive such a term is, they advocate more direct forms of democracy. Equally, their preferred methods of referenda and popular initiatives, are against representative systems from which people feel alienated (1999, p. 7). The extent to which populism is democratic can be understood, according to Canovan, through the tension inherent between redemptive and pragmatic politics. Redemptive politics refers to "the promise of a better world through action by the sovereign people" (p. 11). It strongly relies in the popular voice and involvement of the people. Pragmatic politics, on the other hand, refers to "a system of processing conflicts without killing one another" (p. 10). Where redemptive politics are a call for more democracy, pragmatic politics includes those measures taken to moderate political discourse and those institutions and practices, which evolved out of the tradition of representative governance, that widen the scope of issues and incorporating a larger part of the population within the political arena (p. 11). Populism identifies itself with the redemptive side of democracy, as they claim to represent the people, and are opposed to those systems of pragmatic politics that inhibit their ability to directly participate in the democratic process. Both forms of politics are necessary for a legitimate democracy, as their respective ideals act as necessary countermeasures to one another. Representative systems in place belong to pragmatic politics, and they have distanced themselves from democracy's redemptive side, leaving a vacuum for populism to present itself as real democracy. Waning political participation in western democratic countries therefore does not signify the declining health of democracy, but rather opens the opportunity to consider the norms and structural composition of the current political paradigm. The conclusion that Canovan ultimately draws is that "reflections on populism illuminate the inescapable ambiguity of democracy" (p. 16). As with theories of 
social capital that I have discussed in this chapter, it is not necessary to draw a causal relationship between the occurrence of populist parties with the perceived health of a democracy. Rather, both can serve as opportunities to reflect on representative systems and the normative assumptions within democracy, and the ways in which individuals are able to participate within the political realm.

\section{Conclusion}

Democracy is an elusive concept that is hard to define. Due to its constantly changing nature, any proclamation that it is 'unhealthy' should be analysed, if not viewed with scepticism. One such theory that claims to be indicative of a well-functioning democracy is that of social capital. Within this chapter I have attempted to uncover the normative assumptions underlying the specific theory of social capital by Robert Putnam, who presents it as a diagnostic of democratic health. In doing so I hoped to not only deepen the understanding of that sociological theory, but also to better understand democracy itself. The claim that social capital is the "social networks and the norms of trust and reciprocity associated with them" (Putnam, 2002, p. 5), presents certain difficulties when it is assumed to positively correlate to democratic functioning. I have applied a conceptual analysis to uncover the implicit claims within such conclusions. Historically the term finds its origins in the work of Alexis de Tocqueville, yet its conception relies on a specific reading of Democracy in America (2003). Such an interpretation rests on specific assumptions that are made apparent within the debate between communitarianism and individualism in political philosophy. Liberal criticisms of communitarian thought are against their imposition of a conception of the good onto a community before addressing individual rights. Forms of social capital generated by such bonding, formal, thick, and inward-looking social networks are criticized for not being representative of how political participation is conducted nowadays, and equally for their often coercive, illiberal nature that serves the interest of its members at the expense of outsiders. By uncovering new forms of political participation and by analysing certain theoretical assumptions, such as the necessity of trust, I reject the theory that social capital is declining, and that it is necessarily good for democracy. Such a view of democracy would view recent trends in populist politics as a result of waning democratic health, yet I believe that it is equally a valuable opportunity to reflect on the nature of democracy itself. Perhaps it is not democracy that is in decline, but simply the specific type of representative politics that reflects current forms of political participation. While the studies into new forms of measuring social capital are still recent and on-going, they perhaps provide a good starting point for thinking about the new arenas in which politics are taking place. Change should not always be met with fear and overreactions about the state of democracy, and any theories that measure such change and offer a diagnosis based on their results, deserve closer attention. Democracy is neither healthy nor unhealthy; it's changing. 